\title{
Slipping Through the Pores: Hypoalbuminemia and Albumin Loss During Hemodialysis
}

This article was published in the following Dove Press journal:

International Journal of Nephrology and Renovascular Disease

\author{
Kamyar Kalantar-Zadeh $\left.{ }^{1-3}\right)^{1-3}$ \\ Linda H Ficociello $\mathbb{D D}^{4}$ \\ Jennifer Bazzanella ${ }^{5}$ \\ Claudy Mullon $\mathbb{D}^{4}$ \\ Michael S Anger (iD) ${ }^{4}$ \\ 'Division of Nephrology, Hypertension \\ and Kidney Transplantation, University of \\ California, Irvine, School of Medicine, \\ Orange, CA, USA; ${ }^{2}$ Department of \\ Epidemiology, University of California, \\ Los Angeles (UCLA), Los Angeles, CA, \\ USA; ${ }^{3}$ Los Angeles Biomedical Research \\ Institute at Harbor-UCLA, Torrance, \\ CA, USA; ${ }^{4}$ Fresenius Medical Care Renal \\ Therapies Group, Waltham, MA, USA; \\ ${ }^{5}$ Fresenius Kidney Care, Madison, \\ WI, USA
}

Correspondence: Kamyar Kalantar-Zadeh Division of Nephrology, Hypertension and Kidney Transplantation, University of California, Irvine Medical Center, I0I the City Drive South, Orange, CA 92868-

3217, USA

Tel $+|-7| 4-456-5 \mid 42$

Fax +| -7|4-456-6034

Email kkz@uci.edu

\begin{abstract}
Hypoalbuminemia results when compensatory mechanisms are unable to keep pace with derangements in catabolism/loss and/or decreased synthesis of albumin. Across many disease states, including chronic kidney disease (CKD), hypoalbuminemia is a wellestablished, independent risk factor for adverse outcomes, including mortality. In the setting of CKD, reduced serum albumin concentrations are often a manifestation of protein-energy wasting, a state of metabolic and nutritional alterations resulting in reduced protein and energy stores. The progression of CKD to kidney failure and the initiation of maintenance hemodialysis (HD) further predisposes an already at-risk population toward hypoalbuminemia such that approximately $60 \%$ of HD patients have albumin concentrations $<4.0 \mathrm{~g} / \mathrm{dl}$. Albumin loss into the dialysate through the dialyzer appears to be a potentially modifiable cause of hypoalbuminemia in some patients. A group of newer dialyzers for maintenance HD - sometimes termed protein-leaking or medium cut-off membranes-aim to improve clearance of middle molecules (vs high flux dialyzers) but are associated with increased albumin losses. In this article, we will examine the impact of dialyzer selection on albumin losses during conventional HD, including the clinical relevance of such losses on serum albumin levels. Data on the clinical relevance of albumin losses during dialysis and current gaps in the evidence base are also discussed.
\end{abstract}

Keywords: dialysis membrane, dialyzer, nutrition, hemodialysis, protein-energy wasting

\section{Introduction}

Albumin maintains the vast majority of intravascular colloidal osmotic pressure and plays a crucial role as a carrier protein and antioxidant. ${ }^{1,2}$ Homeostasis of this 66.5 $\mathrm{kDa}$ protein is maintained by the daily synthesis of approximately $10.5 \mathrm{~g}$ to compensate for an equal mass of albumin catabolism, including the relatively small contributions of renal $(\sim 6 \%)$ and gastrointestinal $(\sim 10 \%)$ clearance. $^{2}$ Although albumin levels $>3.5 \mathrm{~g} / \mathrm{dl}$ are generally considered normal, there are data to suggest that levels should be even higher among healthy individuals. ${ }^{2}$ Fulks and colleagues demonstrated that albumin levels $>4.8 \mathrm{~g} / \mathrm{dl}$ were associated with $15 \%$ $18 \%$ relative risk reductions in mortality in an unselected population of men aged 20-49 years. ${ }^{3}$ Similar relationships between albumin levels and mortality were observed in women and in other age groups.

Across disease states, serum albumin concentrations decrease as a result of reduced synthesis and/or increased catabolism such that the protein is considered a negative acute phase reactant. ${ }^{2}$ Increased albumin synthesis, although capable of compensating for some level of increased catabolism, is not without limits. ${ }^{2,4}$ In some cases, increased synthesis of albumin is accompanied by increased synthesis 
of positive acute phase reactants such as fibrinogen. ${ }^{5}$ Independent of the underlying disease state, once compensatory mechanisms are exceeded and synthesis cannot keep up with albumin catabolism, clinically evident hypoalbuminemia will develop. ${ }^{6}$ Low serum concentrations of albumin have been associated with increased mortality risk in clinically stable, hospitalized, and acutely ill patients. ${ }^{7-9}$

Patients with moderate chronic kidney disease (CKD) are frequently found to have reduced serum albumin levels. In data derived from the 1999-2010 National Health and Nutrition Examination Survey (NHANES), $53 \%$ of patients with an estimated glomerular filtration rate (eGFR) $<60 \mathrm{~mL} / \mathrm{min} / 1.73 \mathrm{~m}^{2}$ had albumin levels $<4.2 \mathrm{~g} / \mathrm{dl} .{ }^{10}$ This can be contrasted with $33 \%$ of patients with preserved renal function (ie, eGFR $\geq 90 \mathrm{~mL} / \mathrm{min} /$ $1.73 \mathrm{~m}^{2}$ ) meeting the same criteria. Although the development of hypoalbuminemia in patients with CKD is often multifactorial, the proximate cause is an albumin synthesis rate that is outpaced by catabolic losses. ${ }^{11}$ As observed in the general population and in other disease states, hypoalbuminemia has been associated with increased morbidity and mortality in CKD populations. In the Trial to Reduce Cardiovascular Events With Aranesp Therapy (TREAT), every $1 \mathrm{~g} / \mathrm{dl}$ increase in albumin at baseline was associated with a $42 \%$ reduced risk of kidney failure in a population of adults with type 2 diabetes, CKD, and anemia (median 2.2 year follow-up). ${ }^{12}$ Conversely, in a large retrospective cohort, mortality was incrementally increased as baseline serum albumin decreased below $4.6 \mathrm{~g} / \mathrm{dl} .{ }^{10}$ This relationship was observed across all eGFR categories studied (ie, $30-120 \mathrm{~mL} / \mathrm{min} / 1.73 \mathrm{~m}^{2}$ ).

In addition to being subject to the same predisposing factors experienced by those not requiring kidney replacement therapy, patients receiving maintenance hemodialysis (HD) experience increased protein catabolism, amino acid loss (contributing to malnutrition), and loss of albumin during dialysis. The combination of these factors puts the HD population at yet an even greater risk for hypoalbuminemia. Data from the Dialysis Outcomes and Practice Patterns Study (DOPPS) suggest that $>60 \%$ of HD patients have albumin levels $<4.0 \mathrm{~g} / \mathrm{dl} .{ }^{13}$ Low serum concentrations of albumin have consistently been shown to be a very strong predictor of mortality and morbidity in CKD populations. ${ }^{11,14-20}$ Lowrie and Lew ${ }^{19}$ first demonstrated the association between albumin concentrations and mortality risk in a cohort of more than 12,000 HD patients (Figure 1). These findings were replicated by Owen et $\mathrm{al}^{21}$

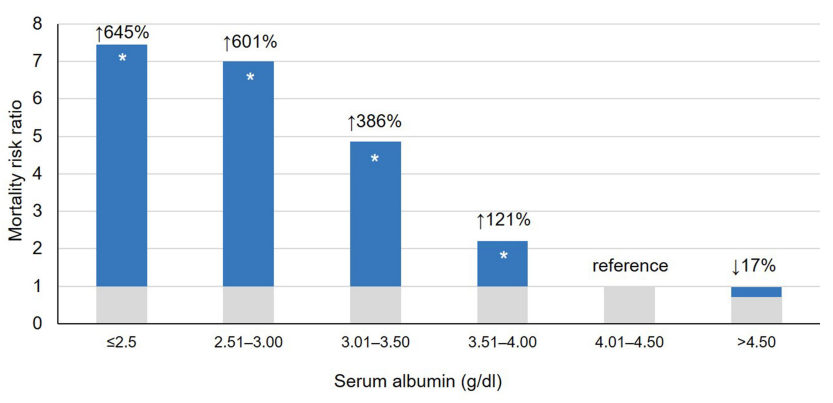

Figure I Relative risk of death by albumin level among 19,746 patients receiving incenter hemodialysis. Data from Lowrie EG, Lew NL. ${ }^{19}$ Data presented as crude risk ratios. $* P<0.05$ vs reference (ie, albumin of $4.01-4.50 \mathrm{~g} / \mathrm{dl}$ ).

in a study of more than $13,000 \mathrm{HD}$ patients; relative to the risk of death among patients with serum albumin levels of $4.0-4.4 \mathrm{~g} / \mathrm{dl}$, mortality was increased $48 \%$ and $213 \%$ among those with serum albumin concentrations of $3.5-3.9 \mathrm{~g} / \mathrm{dl}$ and 3.0-3.4 g/dl, respectively.

Early data linking hypoalbuminemia and increased mortality have since been validated across many studies. A 2010 meta-analysis that included 38 studies and data for 265,330 HD patients demonstrated a clear inverse relationship between serum albumin and mortality (all-cause and cardiovascular). ${ }^{22}$ In a study of a large international cohort of incident HD (vintage $<60$ days at enrollment) patients published in 2020, $19 \%$ of first-year HD deaths were attributable to low serum albumin (ie, $<3.5 \mathrm{~g} / \mathrm{dl}$ ). ${ }^{23}$ The attributable fraction for low serum albumin levels was second only to catheter use. In another recent study of 105 demographic, clinical, and laboratory variables, albumin was identified as the most important predictor of 5 -year mortality among younger HD patients. ${ }^{24}$ Finally, among incident HD patients aged $\geq 65$ years, albumin levels $<3.0 \mathrm{~g} / \mathrm{dl}$ independently predicted a $>3$-fold increased risk of death relative to that observed with albumin levels of $\geq 3.5 \mathrm{~g} / \mathrm{dl}{ }^{25}$ Beyond increased mortality, lower albumin concentrations have also been associated with significant increases in hospital utilization. In an observational study by Rocco and colleagues, patients with albumin concentrations $\leq 3.49 \mathrm{~g} / \mathrm{dl}$ were hospitalized in excess of 7 days more per year than patients with serum albumin $>4.0 \mathrm{~g} / \mathrm{dl} .{ }^{16}$ Using hospitalization expenditure data from the 2018 US Renal Data System Annual Data Report, ${ }^{26}$ these excess hospitalizations could result in an extra $\$ 11,000$ in hospital spending per patient annually. Additionally, in HD populations, hypoalbuminemia is predictive of new and worsening cardiovascular disease ${ }^{27}$ and reduced erythropoietin sensitivity. ${ }^{28}$ 
This article will examine albumin loss during conventional HD through dialyzers, including the loss associated with different types of HD membranes, the clinical relevance of such losses on serum albumin levels, and the research examining the impact of changes in serum albumin levels on outcomes among HD patients.

\section{Causes of Reduced Albumin Levels in the HD Population}

Hypoalbuminemia in the setting of CKD is often a manifestation of protein-energy wasting (PEW). ${ }^{29,30}$ PEW has been defined as a state of metabolic and nutritional alterations characterized by loss of protein and energy stores that leads to muscle and fat loss and cachexia. ${ }^{30-32}$ The risk factors for PEW, and therefore hypoalbuminemia, among patients with CKD are summarized in Figure 2. ${ }^{1,5,11,17,29,33-35}$ Reduced nutritional (protein and caloric) intake can result from anorexia secondary to uremic toxins, slowed gastric emptying, systemic inflammation, and comorbid disorders. ${ }^{29}$ Patients with CKD not receiving kidney replacement therapy are often prescribed dietary restrictions, including recommendations to reduce protein intake. These factors are compounded by increased albumin catabolism and loss. Comorbid illness (eg, infection and cardiovascular disease) can result in hypercatabolism. Renal and gastrointestinal losses of protein (including albumin) can further disrupt albumin homeostasis. ${ }^{1}$ With increased uremia, endocrine disorders (eg, insulin resistance, increased glucagon sensitivity, and hyperparathyroidism) can also impact albumin homeostasis. ${ }^{29,35} \mathrm{PEW}$ places patients at risk for infection, depression, frailty, and cardiovascular disease, which, by contributing to malnutrition and inflammation, can further reduce nutritional status and reinforce a cycle ultimately leading to increasingly severe PEW and hypoalbuminemia. ${ }^{29,30,32,36}$

The progression to kidney failure and initiation of maintenance HD further predisposes an already at-risk population toward hypoalbuminemia (Figure 2). Although patients with CKD G5 treated by dialysis are advised to consume $1.2 \mathrm{~g} / \mathrm{kg}$ /day of protein, ${ }^{30}$ maintaining such an intake can be difficult. In a study conducted among older adults undergoing HD, neither nutritional intervention nor nutritional intervention with a 6-month exercise program resulted in significant albumin increases. ${ }^{37}$ An undesirable consequence of increased dietary protein intake among HD patients is the increased risk of hyperphosphatemia, an independent risk factor for mortality among patients with kidney failure and those on HD. ${ }^{38-41}$ Although a plant-based diet reduces phosphorus intake, ${ }^{40,41}$ approximately $40 \%$ of patients on HD have serum phosphorus levels $>5.5 \mathrm{mg} / \mathrm{dl}^{42}$ and nearly $80 \%$ are treated with phosphate binders. ${ }^{43}$ Data from a recent study suggest that use of the phosphate binder sucroferric oxyhydroxide, with its relatively low pill burden and tolerable gastrointestinal side effect profile, may allow for controlling phosphorus levels without a concomitant decrease in albumin levels. ${ }^{44}$

Inadequate dialysis can further lead to reduced appetite and subsequent malnutrition. ${ }^{17,21}$ Additionally, inadequate dialysis can result in dilutional hypoalbuminemia. Similarly, pre-

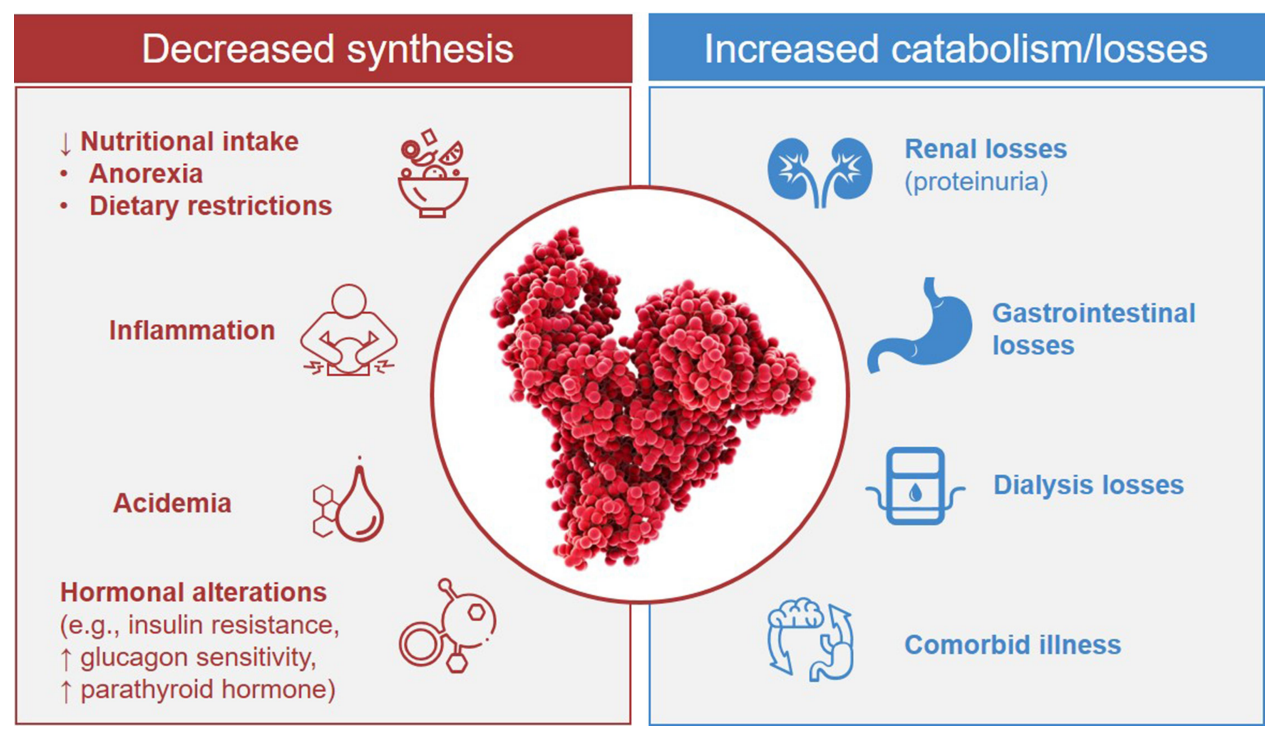

Figure 2 Derangements in albumin homeostasis in patients undergoing hemodialysis. Data from these studies. 1,5, II, 17,29,33-35 
dialysis albumin levels can also be spuriously low secondary to fluid retention. As such, post-HD assessment of albumin levels is considered preferable over pre-HD assessments. ${ }^{45}$

\section{Loss of Albumin During Dialysis}

Hemodialysis equipment, including the dialyzer membrane, results in foreign body exposure capable of triggering an inflammatory state - a known cause of reduced albumin levels. ${ }^{34}$ Current membranes offer similar levels of biocompatibility and represent an improvement over early, regenerated cellulose (ie, Cuprophan $^{\circledR}$ ) membranes. ${ }^{46}$ In addition to protein losses into dialysate (discussed below), protein adsorption to the membrane and tubing can occur. ${ }^{1,29,47}$

Given their small size, a considerable mass of amino acids is lost into the dialysate with each HD session. Data suggest that patients will lose approximately $6-8 \mathrm{~g}$ of total amino acids per session. ${ }^{18,33,35,48}$ Increased membrane surface area and blood flow have both been associated with increased amino acid loss. ${ }^{33,35}$ Larger pores facilitate the removal of water and solute through the membrane but can result in albumin loss. Conversely, smaller pores can impede removal of so-called middle molecules such as $\beta 2$-microglobulin but prevent albumin loss. Although dialyzer reuse is now rare in Europe and North America, it is still a practice common in other parts of the world. ${ }^{49}$ Such practices, including cleaning with bleach, can significantly alter dialyzer permeability and markedly increase albumin losses into the dialysate. ${ }^{11,17,34}$

\section{Impact of Different Dialyzers on Albumin Levels}

The ideal dialyzer facilitates removal of toxins from the blood while avoiding loss of physiologically beneficial molecules. ${ }^{46}$ Until such a dialyzer is developed, the selection of dialyzers should suit the needs of a given patient, with additional consideration to the HD facility and to cost. ${ }^{46,50}$ As will be discussed in greater detail, most membranes used for conventional HD can be broadly categorized as low flux or high flux. Relative to low flux dialyzers, high flux dialyzers offer greater permeability and enhanced removal of toxins with medium and high molecular weights. ${ }^{1}$ A group of newer membranes for maintenance HD - sometimes termed protein-leaking ${ }^{51}$ or medium cut-off $(\mathrm{MCO})^{52}$ membranes - aim to further enhance clearance of middle molecules. In this section, we will examine the albumin losses and impact on serum albumin levels with different dialyzer membranes. Although we will approach our discussion by dialyzer category, it is important to recognize that there is considerable variability in albumin loss within each category. ${ }^{5}$ In a study of "high performance membranes" - a classification system used in Japan - albumin loss per HD session varied from less than $1 \mathrm{~g}$ to nearly $8 \mathrm{~g} .{ }^{53}$

\section{High Flux Membranes}

Representing "a compromise between simplicity and efficiency," dialyzers with high flux membranes are the most commonly used form for maintenance HD. ${ }^{54}$ Over a single dialysis session, albumin loss with high flux membranes is negligible. ${ }^{5,33}$ Because albumin is distributed across intravascular and interstitial compartments, and these compartments are impacted by fluid shifts during HD, albumin losses in the dialysate are not always reflected as reductions in serum albumin after dialysis. In fact, high flux dialyzers are generally associated with initial increases in serum albumin concentrations. Following HD sessions with the Optiflux ${ }^{\circledR}$ F160NR dialyzer (Fresenius Medical Care North America, Waltham, MA, USA), patients experienced an average increase in serum albumin levels of approximately $8 \% .{ }^{55}$ A comparable increase was observed after an initial dialysis session with the Optiflux ${ }^{\circledR}$ Enexa $^{\mathrm{TM}}$ dialyzer, a high flux dialyzer that contains a fluorinated polyurethane surface-modifying macromolecule blended in the membrane during manufacturing. ${ }^{56}$ Such increases likely result from intradialytic fluid loss. ${ }^{45}$ There are data suggesting that longterm HD with (single-use) high flux dialyzers is associated with increases in pre-dialysis serum albumin levels over time. In a study of 976 patients receiving in-center HD with 1 of 4 high flux dialyzers (Optiflux ${ }^{\circledR}$ F160NR, F180NR, F200NR, or F250NR), pre-HD albumin levels demonstrated small but statistically significant increases over 6 months $(0.05-0.11 \mathrm{~g} / \mathrm{dl}) .{ }^{57}$ When the analysis was limited to those 156 patients with hypoalbuminemia ( $\leq 3.5$ $\mathrm{g} / \mathrm{dl}$ ) at baseline, a mean increase in serum albumin of 0.31 $\mathrm{g} / \mathrm{dl}(0.34,0.29$, and $0.28 \mathrm{~g} / \mathrm{dl}$ with the F160NR, F180NR, and F200NR/F250NR dialyzers, respectively) was observed (Figure 3). ${ }^{57}$ The increases in serum albumin levels observed with high flux dialyzer use persist, and possibly increase, over time. In a study of 30 HD patients switched from low flux dialyzers to high flux (FX60; Fresenius, Bad Homburg, Germany) dialyzers, Li and colleagues observed significant increases in serum albumin 


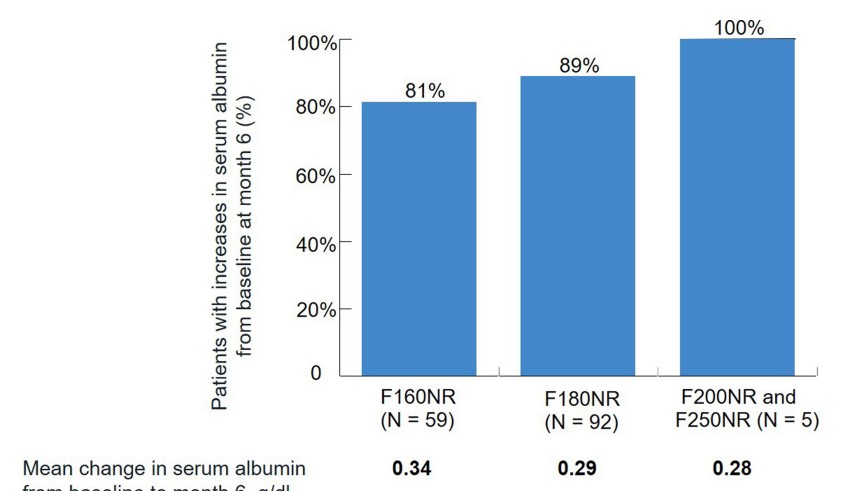

from baseline to month $6, \mathrm{~g} / \mathrm{dl}$

Figure 3 Change in serum albumin levels after 6 months of hemodialysis with different high flux dialyzers among 156 patients with baseline hypoalbuminemia $(\leq 3.5 \mathrm{~g} / \mathrm{dl})$. Data from Zhou et al. ${ }^{57}$

levels after 3 years of use following nonsignificant increases at 1 year. $^{58}$

\section{Protein-Leaking Membranes: Albumin Losses During Dialysis}

Protein-leaking membranes, including MCO membranes, were developed to facilitate removal of larger, middle molecules during HD. ${ }^{5,59}$ These membranes were introduced as early as $1998 .^{60}$ More permeable than high flux membranes, MCO membranes remain less permeable than high cut-off membranes generally reserved for situations in which increased protein removal is therapeutic (eg, multiple myeloma or acute kidney injury secondary to rhabdomyolysis). ${ }^{52}$

In a study of 6 patients receiving $\mathrm{HD}$ with an $\mathrm{MCO}$ dialyzer, albumin losses of 2.0-4.0 g per session were recorded. $^{52}$ Albumin losses associated with MCO membranes were further examined in a pair of prospective, openlabel, controlled, randomized, crossover pilot studies conducted among 39 prevalent HD patients. ${ }^{59}$ In Study 1, the Theranova $400^{\circledR}$ MCO dialyzer (Baxter Healthcare Corporation, Deerfield, IL, USA) was associated with greater albumin losses (median $2.9 \mathrm{~g}$ [range 1.5-3.9]) than the high flux comparators (FX CorDiax 80 and FX CorDiax 800; Fresenius Medical Care Deutschland, Bad Homburg, Germany; median $0.2 \mathrm{~g}$ ). Even greater albumin losses were reported for $2 \mathrm{MCO}$ dialyzer prototypes. In a similarly designed study (ie, Study 2) median albumin losses were $3.2 \mathrm{~g}$ and $0.4 \mathrm{~g}$ with the Theranova 400 dialyzer and high flux dialyzers, respectively. These findings have been replicated in a small $(\mathrm{N}=6)$ study from South Korea demonstrating greater albumin losses with an MCO membrane
(Theranova 400; median $3.16 \mathrm{~g}$ per session) than with a high flux membrane (Rexeed ${ }^{\text {TM}}-21 \mathrm{~A} ;$ Asahi Kasei Medical Co., Ltd., Tokyo, Japan; median 0.06 g per session). ${ }^{61}$ The loss of albumin with MCO dialyzers does not appear to be impacted by increasing the membrane surface from $1.7 \mathrm{~m}^{2}$ (Theranova 400 ) to $2.0 \mathrm{~m}^{2}$ (Theranova $500^{\mathrm{TM}}$; Baxter Healthcare Corporation, Deerfield, IL, USA). ${ }^{62}$ In summary, the median albumin loss per HD session with MCO dialyzers appears to be approximately $3 \mathrm{~g}$, with some variability across individuals.

\section{Protein-Leaking Membranes: Changes in Serum Albumin Levels}

Consistent with the loss of albumin in the dialysate following HD with an MCO dialyzer, most studies have demonstrated reductions in serum albumin concentrations over time with these membranes (Table 1). ${ }^{52,63-73}$ It is worth noting that the analyses in these studies were generally not adjusted for confounding factors that may impact serum albumin levels. In a trial utilizing a prototype MCO membrane (MCO-Ci 400 ${ }^{\circledR}$; Gambro Dialysatoren $\mathrm{GmbH}$, Hechingen, Germany), patients lost an average of $8.5 \mathrm{~g}$ of albumin per session and demonstrated a reduction in serum albumin of approximately $5 \%$ after 4 weeks of use $(P<0.01){ }^{63,64}$ Over the subsequent 8 weeks, nonsignificant increases in serum albumin levels were observed. In a crossover trial comparing the Theranova 400 membrane with conventional high flux membranes (ie, FX8, FX10, FX80, FX100, BK1.6, and BH2.1; Fresenius Medical Care, Bad Homburg, Germany) in prevalent HD patients $(\mathrm{N}=20)$, significant reductions in serum albumin levels (median $0.45 \mathrm{~g} / \mathrm{dl}$ ) were observed during treatment with the MCO membrane. ${ }^{65}$ In a second crossover trial, 3 months of HD with an MCO dialyzer (Theranova 500) was associated with moderate hypoalbuminemia. ${ }^{66}$ Recently published data from the Expanded Hemodialysis Registry Protocol in Colombia (COREXH) Registry from nearly $1000 \mathrm{HD}$ patients also demonstrated statistically significant reductions in serum albumin with MCO membrane use. ${ }^{67}$ Maximal reductions in albumin levels were evident at month 3 . In the small study $(\mathrm{N}=6)$ mentioned previously, Ronco and colleagues did not note changes in serum albumin levels after 6 months of HD with an MCO dialyzer (baseline albumin $\sim 3.5 \mathrm{mg} / \mathrm{dl})^{52}$

In a recent trial of 50 patients randomized to receive 12 weeks of HD with an MCO dialyzer (Theranova 400) or 
Table I Longitudinal Changes in Serum Albumin Concentrations in Studies of Protein-Leaking Dialyzers

\begin{tabular}{|c|c|c|c|c|c|}
\hline \multirow{2}{*}{$\begin{array}{l}\text { Study } \\
\text { Author (Yrl } \\
\text { Country) }\end{array}$} & \multirow{2}{*}{$\begin{array}{l}\text { Patients (N) } \\
\text { Study } \\
\text { Duration }\end{array}$} & \multicolumn{2}{|l|}{ Protein-Leaking Dialyzer } & \multicolumn{2}{|l|}{ High Flux Dialyzer } \\
\hline & & $\begin{array}{l}\text { Baseline Serum } \\
\text { Albumin, g/dl (Dialyzer } \\
\text { Studied) }\end{array}$ & $\begin{array}{l}\text { Change in Serum } \\
\text { Albumin, g/dl }\end{array}$ & $\begin{array}{l}\text { Baseline Serum } \\
\text { Albumin, g/dl } \\
\text { (Dialyzer Studied) }\end{array}$ & $\begin{array}{l}\text { Change in Serum } \\
\text { Albumin, g/dl }\end{array}$ \\
\hline $\begin{array}{l}\text { Zickler et al }{ }^{64} \\
(2017 / \\
\text { Germany) }\end{array}$ & $\begin{array}{l}48 \\
4+8 w k \\
\text { (extension) }\end{array}$ & $\begin{array}{l}3.70(0.36) \\
(\mathrm{MCO}-\mathrm{Ci} 400)\end{array}$ & $\begin{array}{l}\boldsymbol{\nabla} 0.17(4 w k) \\
\nabla 0.06(12 w k)\end{array}$ & $\begin{array}{l}3.66(0.32) \\
\text { (Revaclear } 400 \text { dialyzer) }\end{array}$ & $\begin{array}{l}\Delta 0.09(4 \mathrm{wk}) \\
\Delta 0.12(12 \mathrm{wk})\end{array}$ \\
\hline 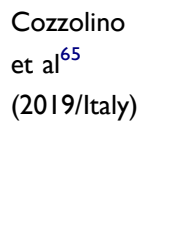 & $\begin{array}{l}20 \\
3 \mathrm{mo}\end{array}$ & $\begin{array}{l}\text { Group A } \\
3.75 \text { ( } 3.10 \text { to } 3.80) \\
\text { Group B } \\
3.80(3.30 \text { to } 4.20) \\
\text { (Theranova } 400)\end{array}$ & $\begin{array}{l}\text { Group A } \\
\Delta 0.04 \text { ( } 0.175 \text { to } 0.375) \\
\text { Group B } \\
\nabla 0.45 \text { (-0.575 to - } \\
0.05)\end{array}$ & $\begin{array}{l}\text { Group A } \\
3.6(3.35 \text { to } 3.80) \\
\text { Group B } \\
3.47(3.05 \text { to } 3.80) \\
(\mathrm{FX} 8, \mathrm{FXI}, \mathrm{FX} 80, \mathrm{FX} \\
100, \mathrm{BKI} .6, \mathrm{BG} 2 . \mathrm{I})\end{array}$ & $\begin{array}{l}\text { Group A } \\
\Delta 0.1(-0.525 \text { to } 0.175) \\
\text { Group B } \\
\Delta 0.34(0.125 \text { to } 0.40)\end{array}$ \\
\hline $\begin{array}{l}\text { Belmouaz } \\
\text { et } \text { al }^{66} \\
\text { (2020/France) }\end{array}$ & $\begin{array}{l}40 \\
6 \mathrm{mo}\end{array}$ & $\begin{array}{l}3.73(0.3 \mathrm{I}) \\
\text { (Theranova 500) }\end{array}$ & $\boldsymbol{\nabla} 0.04$ & $\begin{array}{l}3.73(0.3 \mathrm{I}) \\
\left.\text { Elisio }^{\mathrm{TM}}-2 \mathrm{IH}\right)\end{array}$ & $\Delta 0.09$ \\
\hline $\begin{array}{l}\text { Krishnasamy } \\
\text { et } \mathrm{al}^{71} \\
(2020 / \\
\text { Australia) }\end{array}$ & $\begin{array}{l}89 \\
24 w k\end{array}$ & $\begin{array}{l}3.58(0.39) \\
\text { (Theranova 400) }\end{array}$ & $\boldsymbol{\nabla} 0.07(-1.5 \text { to } 0.1)^{*}$ & No control group & No control group \\
\hline $\begin{array}{l}\text { Lim et al }{ }^{69} \\
(2020 / \text { South } \\
\text { Korea) }\end{array}$ & $\begin{array}{l}49 \\
12 w k\end{array}$ & $\begin{array}{l}4.1 I(0.38) \\
\text { (Theranova } 400)\end{array}$ & $\boldsymbol{\nabla} 0.13$ & $\begin{array}{l}4.06(0.27) \\
\text { (FX CorDiax } 60 \text { or } 80)\end{array}$ & $\boldsymbol{\nabla} 0.02$ \\
\hline $\begin{array}{l}\text { Sevinc et al }{ }^{70} \\
\text { (2020/Turkey) }\end{array}$ & $\begin{array}{l}52 \\
3 \mathrm{mo}\end{array}$ & $\begin{array}{l}3.88 \text { (3.7I to } 4.04) \\
\text { (Theranova } 500)\end{array}$ & $\boldsymbol{\nabla} 0.26$ & $\begin{array}{l}3.75 \text { (3.59 to } 3.95) \\
\text { (FX CorDiax } 80)\end{array}$ & $\Delta 0.03$ \\
\hline $\begin{array}{l}\text { Bunch et al }{ }^{67} \\
(2020 / \\
\text { Colombia) }\end{array}$ & $\begin{array}{l}992 \\
12 \mathrm{mo}\end{array}$ & $\begin{array}{l}4.05 \text { (4.04 to } 4.07) \\
\text { (Theranova } \mathrm{MCO} \\
\text { dialyzer) }\end{array}$ & $\begin{array}{ll}\boldsymbol{\nabla} & 0.14(3 \mathrm{mo}) \\
\nabla & 0.07(12 \mathrm{mo})\end{array}$ & No control group & No control group \\
\hline $\begin{array}{l}\text { Yeter et al }{ }^{68} \\
(2020 / \text { Turkey) }\end{array}$ & $\begin{array}{l}42 \\
6 \mathrm{mo}\end{array}$ & $\begin{array}{l}4.0(0.25) \\
(\text { Theranova } 400)\end{array}$ & $\nabla 0.16$ & $\begin{array}{l}3.96(0.23) \\
\text { (Fresenius CorDiax } 800 \\
\text { HDF) }\end{array}$ & $\boldsymbol{\nabla} 0.07$ \\
\hline
\end{tabular}

Notes: Data listed as mean, mean (SD), or median (interquartile range) unless otherwise noted. ${ }^{*}$ Data listed as mean $(95 \% \mathrm{Cl})$. $\boldsymbol{\nabla}=$ reduction from baseline; $\boldsymbol{\Delta}=$ increase from baseline.

with a high flux (FX CorDiax 60 or 80 ) dialyzer, serum albumin levels decreased by a mean (SD) of $0.13(0.23) \mathrm{g} / \mathrm{l}$ in the MCO group. ${ }^{69}$ There was a $0.02 \mathrm{~g} / \mathrm{dl}$ mean decrease in albumin levels among patients receiving HD with the high flux dialyzer. In a separate randomized, prospective, open-label, crossover study, 3 months of HD with MCO dialyzers (Theranova 500) resulted in significant decreases in pre-dialysis serum albumin levels. ${ }^{70}$ In contrast, nonsignificant increases in serum albumin levels were observed after 3 months of HD with high flux dialyzers (FX CorDiax 80 dialyzer).

The impact of long-term HD with an MCO membrane was evaluated in the open-label, nonrandomized Trial Evaluating
Mid Cut-Off Value Membrane Clearance of Albumin and Light Chains in Haemodialysis Patients (REMOVAL-HD) .$^{71,72}$ Across 9 HD facilities in Australia and New Zealand, 89 participants underwent a 4-week wash-in period, during which they received HD with a high flux dialyzer. Patients then received 24 weeks of HD with an MCO dialyzer (Theranova 400). Serum albumin levels were reduced from baseline by an average of $0.07 \mathrm{~g} / \mathrm{dl}(95 \% \mathrm{CI}-0.15$ to 0.01$)$ at 6 months. ${ }^{71}$ Notably, use of the MCO dialyzer did not result in improvements in quality of life, restless leg symptoms, functional status (as assessed by the 6-minute walk test), or nutritional status (as assessed by the Malnutrition Inflammation Score). The longterm effects of an MCO dialyzer in a conventional HD setting 
were also studied by Cho et al. ${ }^{73}$ In a cohort of 57 patients, serum albumin levels did not significantly decrease over the course of a year. The researchers proposed that increases in hepatic albumin synthesis were able to compensate for albumin lost during dialysis. Note that the mean (SD) baseline serum albumin level in the study population was $3.96(0.31)$ $\mathrm{g} / \mathrm{dl}$. We suggest that the capability to significantly increase albumin synthesis, although present in patients with normal albumin levels, may be limited in patients with hypoalbuminemia at baseline and those with systemic inflammation and albumin catabolism exceeding albumin synthesis.

\section{Clinical Outcomes Associated with Temporal Changes in Serum Albumin Levels}

Whereas ample data support an association between hypoalbuminemia and poor outcomes, and growing evidence has demonstrated greater albumin losses with MCO dialyzers (vs high flux dialyzers), data to suggest that correction or preservation of serum albumin levels improves mortality and/or morbidity in HD patients are limited. In a large cohort of HD patients $(\mathrm{N}=30,827)$, those whose serum albumin increased by $\geq 0.3 \mathrm{~g} / \mathrm{dl}$ within 6 months were $22 \%$ less likely to die within 18 months than those with stable serum albumin levels (Figure 4). ${ }^{74}$ Based on these data, it has been suggested that interventions capable of increasing serum albumin to levels $>3.8 \mathrm{~g} /$ dl could prevent approximately 10,000 deaths among HD patients each year in the United States. Conversely, even

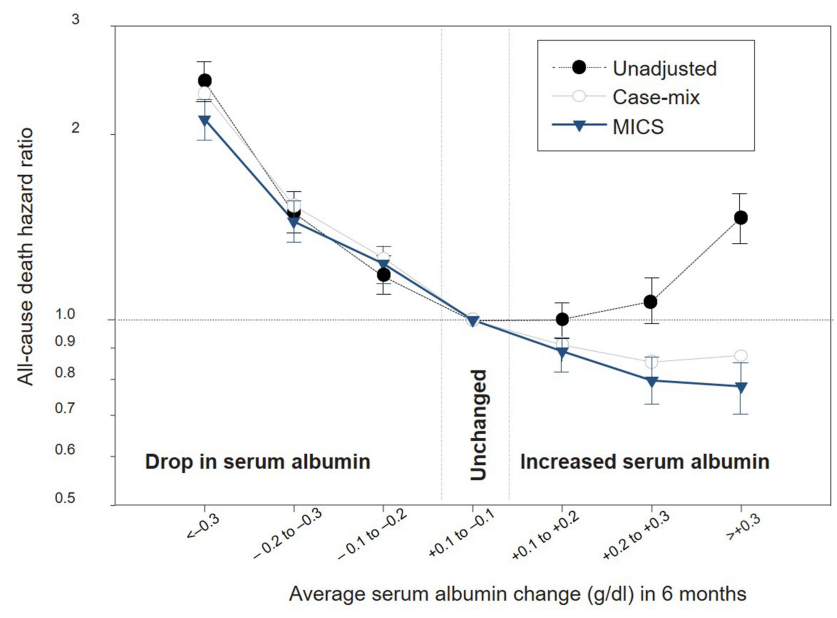

Figure 4 Impact of temporal changes in serum albumin levels on subsequent mortality risk. MICS, malnutrition-inflammation complex syndrome. Reproduced from KalantarZadeh K, Kilpatrick RD, Kuwae N, et al. Revisiting mortality predictability of serum albumin in the dialysis population: time dependency, longitudinal changes and populationattributable fraction. Nephrology Dialysis Transplant. 2020;20(9):1880-1888, by permission of Oxford University Press. ${ }^{74}$ modest reductions in serum albumin levels of $0.1-0.2 \mathrm{~g} / \mathrm{dl}$ - as observed with many of the studies of protein-leaking dialyzers described above-were associated with significant increases in mortality. Reductions in serum albumin levels of $0.3 \mathrm{~g} / \mathrm{dl}$ or greater were associated with a doubling of mortality risk.

\section{Current Evidence Base and Conclusions}

For more than a quarter of a century, we have recognized that reduced levels of serum albumin predict morbidity and mortality among HD patients. A multitude of factors contribute to PEW and the associated risk of hypoalbuminemia in patients with CKD. Many causes such as inflammation, endocrinopathies, renal dysfunction, and acidemia are inherent to $\mathrm{CKD}$ and only partially modifiable. Reduced nutritional intake of protein - a key component of PEW - is a manifestation of the complex interactions among physician-prescribed dietary recommendations, comorbid illness, disease-associated anorexia, social and physical constraints, and inflammation. In one study, by the time patients reached kidney failure, only $11 \%$ were found to have albumin concentrations of $4.0 \mathrm{~g} / \mathrm{dl}$, and more than $36 \%$ had levels $<3.0 \mathrm{~g} / \mathrm{dl} .{ }^{75}$ Hemodialysis can put patients at even greater risk of hypoalbuminemia as a result of further impairment of nutritional intake and nutrient and albumin losses during dialysis. Whereas amino acid loss occurs with all conventional HD dialyzers, albumin losses into the dialysate appear to vary greatly depending on the dialyzer used. Although there are no head-to-head randomized controlled trials comparing the long-term outcomes associated with different dialyzers, an "excessive" loss of albumin is a theoretical concern with the chronic use of increasingly permeable dialyzers. ${ }^{59}$ A recent evaluation of $2 \mathrm{MCO}$ dialyzers (Theranova 400 and 500) by the Centers for Medicare \& Medicaid Services (CMS) noted "there may be increased removal of albumin with MCO membranes compared to conventional high-flux dialysis, which could have negative health consequences."76

To date, no definition of "excessive" albumin loss during dialysis has been proposed or accepted. ${ }^{63}$ For context, the loss of 3.0-3.5 g of protein per day via urine would satisfy diagnostic criteria for proteinuria associated with nephrotic syndrome. Whereas the use of MCO dialyzers appears to result in a similar magnitude of albumin loss, the impact of these dialyzers on serum albumin levels is quite variable. ${ }^{51}$ Temporal changes in serum albumin 
levels - even modest changes (0.1-0.2 g/dl) - have been shown to significantly impact survival. ${ }^{74}$ Such data, although not adjusted for dialyzer type or middle molecule removal, suggest that minor reductions in serum albumin are associated with increased all-cause and cardiovascular mortality.

The potential impact of replacing use of high flux membranes with use of MCO membranes to increase removal of middle molecules remains understudied. MCO membranes were developed to help determine whether the retention of medium-high molecular weight solutes contributes to poor clinical consequences and whether removal of those middle molecules during HD improves outcomes. ${ }^{54}$ To date, no strong evidence supports a survival benefit associated with increasing removal of middle molecules. ${ }^{1,77,78}$ Available data comparing MCO and high flux dialyzers are derived from small observational studies. Such studies have a high potential for bias. Furthermore, although derived from subgroup analyses, data from the Membrane Permeability Outcome study suggest a survival benefit associated with use of a high flux dialyzer (vs a low flux dialyzer) among patients with serum albumin $<4.0 \mathrm{~g} / \mathrm{dl}$ (hazard ratio [95\% CI] 0.63 [0.45-0.90]; $P=0.010){ }^{78}$ The lack of clear clinical benefit with MCO dialyzers was a key conclusion in the aforementioned CMS review of $2 \mathrm{MCO}$ dialyzers. ${ }^{76}$

The available data comparing the impact of dialyzers of differing permeability on serum albumin levels and clinical outcomes, although informative, are not without limitations. Whereas increased albumin losses may have nondetrimental effects among patients with the ability to mount compensatory responses, patients at particularly high risk for derangements in albumin synthesis (eg, liver disease, poor nutrition) may be unable to mount such a response. We are unaware of studies devoted to studying the effects of different dialyzers among such patients. Similarly, the results of studies of short duration may not adequately capture long-term trends or reflect changes in compensatory mechanisms over time or with worsening underlying health status. Conversely, while data conclusively demonstrate an association between low serum albumin levels and adverse outcomes, they do not, even with multivariate adjustment, establish causality. In several studies, the role of serum albumin as a predictive marker for mortality was observed only among patients exhibiting evidence of inflammation or an acute-phase response (eg, elevated levels of C-reactive protein). ${ }^{79-81}$ Albumin levels have also been considered a surrogate for the broader nutritional status of patients. ${ }^{2}$ Thus, low albumin levels, although predictive of increased mortality, may not be the proximate cause of adverse outcomes in HD patients. ${ }^{17}$ Reduced albumin levels can also be indicative of comorbid illnesses (eg, hepatic disease) capable of adversely impacting survival.

Although we know from DOPPS data that a majority of HD patients have serum albumin levels $<4.0 \mathrm{~g} / \mathrm{dl},{ }^{13}$ patients with hypoalbuminemia appear to be underrepresented in many of the studies detailed above. This discrepancy might, in part, result from study designs that exclude patients with serious comorbid illnesses that can negatively impact albumin levels. Future studies should examine the effects of dialyzer selection among patient cohorts with moderate to severe hypoalbuminemia.

Conventional HD is one of many factors contributing to the risk of hypoalbuminemia in the setting of kidney failure. Strategies for reducing the risk of hypoalbuminemia in this population include improving systemic inflammation, preventing infection, optimizing nutritional status, and ensuring the appropriate management of comorbid conditions. Albumin loss secondary to increased clearance into dialysate appears capable of impacting serum albumin levels in at-risk patients. With an increasing number of dialyzer options, there is a need to further examine the clinical effects of removal of middle molecules at the "expense" of albumin loss. Large clinical studies of longer duration are needed, as there is insufficient clinical evidence regarding the safety and efficacy of protein-leaking membranes. Head-to-head trials examining laboratory parameters, quality of life, and clinical endpoints (including survival) represent the preferred method for addressing many of the open clinical questions. Until the availability of such data, clinicians should be mindful of dialysis-associated albumin losses and consider dialyzer changes (eg, discontinuation/avoidance of proteinleaking membranes) and/or nutritional interventions (eg, intradialytic nutritional supplements), particularly among patients with evidence of hypoalbuminemia.

\section{Acknowledgment}

Medical writing and editing support were provided by Adam Perahia, MD, of NorthStar Strategic Consulting, LLC, via funding by Fresenius Medical Care Renal Therapies Group.

\section{Author Contributions}

All authors made substantial contributions to conception and design, acquisition of data, or analysis and interpretation of data; took part in drafting the article or revising it 
critically for important intellectual content; agreed to submit to the current journal; gave final approval of the version to be published; and agree to be accountable for all aspects of the work.

\section{Funding}

Writing and editorial support funded by Fresenius Medical Care Renal Therapies Group.

\section{Disclosure}

$\mathrm{KK}-\mathrm{Z}$ has received honoraria and/or support from Abbott, AbbVie, Alexion, American Society of Nephrology, Amgen, AstraZeneca, AVEO, Chugai, DaVita, Fresenius, Fresenius Kabi, Genentech, Haymarket Media, Hospira, International Federation of Kidney Foundations, International Society for Hemodialysis, International Society of Renal Nutrition and Metabolism, Japanese Society for Dialysis Therapy, Keryx, National Institutes of Health, National Kidney Foundation, Novartis, OPKO, Pfizer, Relypsa, Resverlogix, Sandoz, Sanofi, Shire, UpToDate, Vifor, ZS Pharma, and Zucker School of Medicine. LHF, CM, and MSA are employees of Fresenius Medical Care Renal Therapies Group. CM is a stockholder in Fresenius Medical Care. JB is an employee of Fresenius Kidney Care and consultant to Fresenius Medical Care Renal Therapies Group. The authors report no other conflicts of interest in this work.

\section{References}

1. Ward RA, Beck W, Bernardo AA, et al. Hypoalbuminemia: a price worth paying for improved dialytic removal of middle-molecularweight uremic toxins? Nephrol Dial Transplant. 2019;34(6):901-907. doi:10.1093/ndt/gfy236

2. Levitt DG, Levitt MD. Human serum albumin homeostasis: a new look at the roles of synthesis, catabolism, renal and gastrointestinal excretion, and the clinical value of serum albumin measurements. Int J Gen Med. 2016;9:229-255. doi:10.2147/IJGM.S102819

3. Fulks M, Stout RL, Dolan VF. Albumin and all-cause mortality risk in insurance applicants. J Insur Med. 2010;42:11-17.

4. Schomerus H, Mayer G. Synthesis rates of albumin and fibrinogen in patients with protein-losing enteropathy and in a patient recovering from protein malnutrition. Digestion. 1975;13(4):201-208. doi:10.11 59/000197709

5. van Gelder MK, Abrahams AC, Joles JA, et al. Albumin handling in different hemodialysis modalities. Nephrol Dial Transplant. 2018;33 (6):906-913. doi:10.1093/ndt/gfx191

6. Krieter DH, Canaud B. High permeability of dialysis membranes: what is the limit of albumin loss? Nephrol Dial Transplant. 2003;18 (4):651-654. doi:10.1093/ndt/gfg054

7. Akirov A, Masri-Iraqi H, Atamna A, et al. Low albumin levels are associated with mortality risk in hospitalized patients. $\mathrm{Am} \mathrm{J} \mathrm{Med}$. 2017;130(12):1465.e11-1465.e19. doi:10.1016/j.amjmed.2017.07.020
8. Cabrerizo S, Cuadras D, Gomez-Busto F, et al. Serum albumin and health in older people: review and meta analysis. Maturitas. 2015;81:17-27. doi:10.1016/j.maturitas.2015.02.009

9. Jellinge ME, Henriksen DP, Hallas P, et al. Hypoalbuminemia is a strong predictor of 30-day all-cause mortality in acutely admitted medical patients: a prospective, observational, cohort study. PLoS One. 2014;9:e105983. doi:10.1371/journal.pone.0105983

10. Brown-Tortorici AR, Naderi N, Tang Y, et al. Serum albumin is incrementally associated with increased mortality across varying levels of kidney function. Nutrition. 2020;79-80:110818. doi:10.10 16/j.nut.2020.110818

11. Kaysen GA, Rathore V, Shearer GC, et al. Mechanisms of hypoalbuminemia in hemodialysis patients. Kidney Int. 1995;48(2):510-516. doi:10.1038/ki.1995.321

12. Mc Causland FR, Claggett B, Burdmann EA, et al. C-reactive protein and risk of ESRD: results from the Trial to Reduce Cardiovascular Events With Aranesp Therapy (TREAT). Am J Kidney Dis. 2016;68 (6):873-881. doi:10.1053/j.ajkd.2016.07.022

13. US-DOPPS (Dialysis Outcomes and Practice Patterns Study) Practice Monitor. Serum albumin (3 month average), categories; 2020. https:// www.dopps.org/DPM/Files/meanalbumingdl_c_overallTAB.htm. Accessed May 25, 2020.

14. Lacson E, Wang W, Hakim RM, et al. Associates of mortality and hospitalization in hemodialysis: potentially actionable laboratory variables and vascular access. Am J Kidney Dis. 2009;53(1):79-90. doi:10.1053/j.ajkd.2008.07.031

15. Kalantar-Zadeh K, Ikizler TA. Let them eat during dialysis: an overlooked opportunity to improve outcomes in maintenance hemodialysis patients. J Ren Nutr. 2013;23(3):157-163. doi:10.1053/j.jrn.20 12.11.001

16. Rocco MV, Soucie JM, Reboussin DM, et al. Risk factors for hospital utilization in chronic dialysis patients. Southeastern Kidney Council (Network 6). J Am Soc Nephrol. 1996;7:889-896.

17. Yeun JY, Kaysen GA. Factors influencing serum albumin in dialysis patients. Am J Kidney Dis. 1998;32(6):S118-S125. doi:10.1016/ s0272-6386(98)70174-X

18. Kistler BM, Benner D, Burrowes JD, et al. Eating during hemodialysis treatment: a consensus statement from the International Society of Renal Nutrition and Metabolism. J Ren Nutr. 2018;28:4-12. doi:10.1053/j.jrn.2017.10.003

19. Lowrie EG, Lew NL. Death risk in hemodialysis patients: the predictive value of commonly measured variables and an evaluation of death rate differences between facilities. Am J Kidney Dis. 1990;15 (5):458-482. doi:10.1016/s0272-6386(12)70364-5

20. Beto JA, Bansal VK, Hart J, et al. Hemodialysis prognostic nutrition index as a predictor for morbidity and mortality in hemodialysis patients and its correlation to adequacy of dialysis. Council on Renal Nutrition National Research Question Collaborative Study Group. J Ren Nutr. 1999;9(1):2-8. doi:10.1016/s1051-2276(99) 90015-8

21. Owen WF, Lew NL, Liu Y, et al. The urea reduction ratio and serum albumin concentration as predictors of mortality in patients undergoing hemodialysis. $N$ Engl J Med. 1993;329(14):1001-1006. doi:10.1056/NEJM199309303291404

22. Herselman M, Esau N, Kruger JM, et al. Relationship between serum protein and mortality in adults on long-term hemodialysis: exhaustive review and meta-analysis. Nutrition. 2010;26(1):10-32. doi:10.1016/ j.nut.2009.07.009

23. Karaboyas A, Morgenstern H, Li Y, et al. Estimating the fraction of first-year hemodialysis deaths attributable to potentially modifiable risk factors: results from the DOPPS. Clin Epidemiol. 2020; 12:51-60. doi:10.2147/CLEP.S233197

24. Gotta V, Tancev G, Marsenic O, et al. Identifying key predictors of mortality in young patients on chronic haemodialysis - a machine learning approach. Nephrol Dial Transplant. 2020. doi:10.1093/ndt/ gfaa 128 
25. Santos J, Oliveira P, Malheiro J, et al. Predicting 6-month mortality in incident elderly dialysis patients: a simple prognostic score. Kidney Blood Press Res. 2020;45(1):38-50. doi:10.1159/000504136

26. Saran R, Robinson B, Abbott KC, et al. US Renal Data System 2018 Annual Data Report: epidemiology of kidney disease in the United States. Am J Kidney Dis. 2019;73(suppl1):S772. doi:10.1053/j. ajkd.2019.01.001

27. Foley RN, Parfrey PS, Harnett JD, et al. Hypoalbuminemia, cardiac morbidity, and mortality in end-stage renal disease. $J \mathrm{Am} S o c$ Nephrol. 1996;7:728-736.

28. Agarwal R, Davis JL, Smith L. Serum albumin is strongly associated with erythropoietin sensitivity in hemodialysis patients. Clin $\mathrm{J} \mathrm{Am}$ Soc Nephrol. 2008;3(1):98-104. doi:10.2215/CJN.03330807

29. Kalantar-Zadeh K, Ikizler TA, Block G, et al. Malnutritioninflammation complex syndrome in dialysis patients: causes and consequences. Am J Kidney Dis. 2003;42(5):864-881. doi:10.1016/ j.ajkd.2003.07.016

30. Hanna RM, Ghobry L, Wassef $\mathrm{O}$, et al. A practical approach to nutrition, protein-energy wasting, sarcopenia, and cachexia in patients with chronic kidney disease. Blood Purif. 2020;49:20 2-211. doi:10.1159/000504240

31. Fouque D, Kalantar-Zadeh K, Kopple J, et al. A proposed nomenclature and diagnostic criteria for protein-energy wasting in acute and chronic kidney disease. Kidney Int. 2008;73:391-398. doi:10.1038/sj. ki.5002585

32. Obi Y, Qader H, Kovesdy CP, et al. Latest consensus and update on protein-energy wasting in chronic kidney disease. Curr Opin Clin Nutr Metab Care. 2015;18(3):254-262. doi:10.1097/MCO.0000000 000000171

33. Ikizler TA, Flakoll PJ, Parker RA, et al. Amino acid and albumin losses during hemodialysis. Kidney Int. 1994;46(3):830-837. doi:10.1038/ki.1994.339

34. Rault RM. Effects of dialyzer membrane on serum albumin levels in patients receiving hemodialysis. Int $J$ Artif Organs. 2003;26 (11):1002-1004. doi:10.1177/039139880302601106

35. Gil H-W, Yang J-O, Lee E-Y, et al. The effect of dialysis membrane flux on amino acid loss in hemodialysis patients. J Korean Med Sci. 2007;22(4):598-603. doi:10.3346/jkms.2007.22.4.598

36. Kalantar-Zadeh K, Kopple JD. Relative contributions of nutrition and inflammation to clinical outcome in dialysis patients. Am J Kidney Dis. 2001;38(6):1343-1350. doi:10.1053/ajkd.2001.29250

37. Hristea D, Deschamps T, Paris A, et al. Combining intra-dialytic exercise and nutritional supplementation in malnourished older haemodialysis patients: towards better quality of life and autonomy. Nephrology. 2016;21(9):785-790. doi:10.1111/nep.12752

38. Zitt E, Lamina C, Sturm G, et al. Interaction of time-varying albumin and phosphorus on mortality in incident dialysis patients. Clin $\mathrm{J} \mathrm{Am}$ Soc Nephrol. 2011;6(11):2650-2656. doi:10.2215/CJN.03780411

39. Hou Y, Li X, Sun L, et al. Phosphorus and mortality risk in end-stage renal disease: a meta-analysis. Clin Chim Acta. 2017;474:108-113. doi:10.1016/j.cca.2017.09.005

40. Garcia-Torres R, Young L, Murray DP, et al. Dietary protein source and phosphate levels in patients on hemodialysis. J Ren Nutr. 2020;30(5):423-429. doi:10.1053/j.jrn.2019.11.006

41. Ketteler M, Block GA, Evenepoel P, et al. Executive summary of the 2017 KDIGO Chronic Kidney Disease-Mineral and Bone Disorder (CKD-MBD) Guideline Update: what's changed and why it matters. Kidney Int. 2017;92(1):26-36. doi:10.1016/j.kint.2017.04.006

42. US-DOPPS (Dialysis Outcomes and Practice Patterns Study) Practice Monitor. Serum phosphorus (3 month average), categories. 2020; https://www.dopps.org/DPM/Files/meanphosphmgdl_c_overallTAB. htm. Accessed May 25, 2020.

43. US-DOPPS (Dialysis Outcomes and Practice Patterns Study) Practice Monitor. Phosphate binder use, last 1 month.2020; https://www. dopps.org/DPM/Files/PBINDER_use_c_overallTAB.htm. Accessed May 25, 2020.
44. Kalantar-Zadeh K, Ficociello LH, Parameswaran V, et al. Changes in serum albumin and other nutritional markers when using sucroferric oxyhydroxide as phosphate binder among hemodialysis patients: a historical cohort study. BMC Nephrol. 2019;20(1):396. doi:10.11 86/s12882-019-1582-9

45. Kubrusly M, Oliveira CMCD, Santos DCDO, et al. Análise comparativa entre a albumina pré- e pós-dialise como indicadores do risco nutricional e de morbimortalidade em hemodiálise. $J$ Brasileiro De Nefrologia. 2012;34(1):27-35. doi:10.1590/S0101-28002012000100 005

46. Haroon S, Davenport A. Choosing a dialyzer: what clinicians need to know. Hemodialysis Int. 2018;22(S2):S65-S74. doi:10.1111/hdi.12 702

47. Tomisawa N, Yamashita AC. Amount of adsorbed albumin loss by dialysis membranes with protein adsorption. $J$ Artif Organs. 2009;12 (3):194-199. doi:10.1007/s10047-009-0469-0

48. Lacson LE, Wang W, Zebrowski B, et al. Outcomes associated with intradialytic oral nutritional supplements in patients undergoing maintenance hemodialysis: a quality improvement report. $\mathrm{Am}$ J Kidney Dis. 2012;60(4):591-600. doi:10.1053/j.ajkd.2012.04.019

49. Upadhyay A. Dialyzer reuse: is it safe and worth it? Br J Nephrology. 2019;41(3):312-314. doi:10.1590/2175-8239-JBN-2019-0134

50. Okuno S, Ishimura E, Kohno K, et al. Serum 2-microglobulin level is a significant predictor of mortality in maintenance haemodialysis patients. Nephrol Dial Transplant. 2008;24(2):571-577. doi:10.1093/ndt/gfn521

51. Ward RA. Protein-leaking membranes for hemodialysis: a new class of membranes in search of an application? J Am Soc Nephrol. 2005;16(8):2421-2430. doi:10.1681/ASN.2005010070

52. Ronco C, Marchionna N, Brendolan A, et al. Expanded haemodialysis: from operational mechanism to clinical results. Nephrol Dial Transplant. 2018;33(suppl_3):iii41-iii47. doi:10.1093/ndt/gfy202

53. Tsuchida K, Minakuchi J. Albumin loss under the use of the high-performance membrane. Contrib Nephrol. 2011;173:76-83. doi:10.1159/000328957

54. Ronco C, La Manna G. Expanded hemodialysis: a new therapy for a new class of membranes. Contrib Nephrol. 2017;190:124-133. doi:10.1159/000468959

55. Meyer JM, Steer D, Weber LA, et al. Clinical performance of the Optiflux ${ }^{\circledR}$ F160NR dialyzer. National Kidney Foundation 2020 Spring Clinical Meetings; 26-29, 2020

56. Meyer JM, Steer D, Weber LA, et al. Clinical Study to Assess the Performance of a Novel Dialyzer with Endexo ${ }^{\mathrm{TM}}$ in ESRD Subjects. American Society of Nephrology Kidney Week 2019; November 8, 2019. Washington, DC: Abstract FR-P0474; 2020.

57. Zhou M, Ficociello LH, Costanzo M, et al. Evaluation of biomarkers in chronic hemodialysis (HD) patients dialyzed with Optiflux high-flux dialyzers. National Kidney Foundation 2020 Spring Clinical Meetings 2020282.

58. Li Y, Wang Y, Lv J, et al. Clinical outcomes for maintenance hemodialysis patients using a high-flux (FX60) dialyzer. Ren Fail. 2013;35 (9):1240-1245. doi:10.3109/0886022X.2013.823872

59. Kirsch AH, Lyko R, Nilsson L-G, et al. Performance of hemodialysis with novel medium cut-off dialyzers.. Nephrol Dial Transplant. 2017;32(1):165-172. doi:10.1093/ndt/gfw310

60. Ronco C, Orlandini G, Brendolan A, et al. Enhancement of convective transport by internal filtration in a modified experimental hemodialyzer: technical note. Kidney Int. 1998;54(3):979-985. doi:10.10 46/j.1523-1755.1998.00049.x

61. Kim TH, Kim S-H, Kim TY, et al. Removal of large middle molecules via haemodialysis with medium cut-off membranes at lower blood flow rates: an observational prospective study. BMC Nephrol. 2020;21(1):2. doi:10.1186/s12882-019-1669-3

62. Maduell F, Rodas L, Broseta JJ, et al. Valoración de la influencia de la superficie de la membrana y el flujo sanguíneo en dializadores de medio cut-off. Nefrología. 2019;39(6):623-628. doi:10.1016/j.nefro. 2019.02.006 
63. Boschetti-de-Fierro A, Beck W, Hildwein H, et al. Membrane innovation in dialysis. Contrib Nephrol. 2017;191:100-114. doi:10.1159/000479259

64. Zickler D, Schindler R, Willy K, et al. Medium cut-off (MCO) membranes reduce inflammation in chronic dialysis patients - a randomized controlled clinical trial. PLoS One. 2017;12(1):e0169024. doi:10.1371/journal.pone.0169024

65. Cozzolino M, Magagnoli L, Ciceri P, et al. Effects of a medium cutoff $\left(\right.$ Theranova $\left.{ }^{\circledR}\right)$ dialyser on haemodialysis patients: a prospective, cross-over study. Clin Kidney J. 2020. doi:10.1093/ckj/sfz155

66. Belmouaz M, Bauwens M, Hauet T, et al. Comparison of the removal of uraemic toxins with medium cut-off and high-flux dialysers: a randomized clinical trial.. Nephrol Dial Transplant. 2020;35 (2):328-335. doi:10.1093/ndt/gfz189

67. Bunch A, Sanchez R, Nilsson L-G, et al. Medium cut-off dialyzers in a large population of hemodialysis patients in Colombia: COREXH registry. Ther Apher Dial. 2020. doi:10.1016/j.nut.2020.110818

68. Yeter HH, Korucu B, Akcay OF, et al. Effects of medium cut-off dialysis membranes on inflammation and oxidative stress in patients on maintenance hemodialysis. Int Urol Nephrol. 2020;52 (9):1779-1789. doi:10.1007/s11255-020-02562-3

69. Lim J-H, Park Y, Yook J-M, et al. Randomized controlled trial of medium cut-off versus high-flux dialyzers on quality of life outcomes in maintenance hemodialysis patients. Sci Rep. 2020;10(1):7780. doi:10.1038/s41598-020-64622-z

70. Sevinc M, Hasbal NB, Yilmaz V, et al. Comparison of circulating levels of uremic toxins in hemodialysis patients treated with medium cut-off membranes and high-flux membranes: theranova in Sisli Hamidiye Etfal (THE SHE) randomized control study. Blood Purification. 2018;49(6):733-742. doi:10.1053/j.jrn.2017.10.003

71. Krishnasamy R, Hawley CM, Jardine MJ, et al. A tRial Evaluating Mid Cut-Off Value Membrane Clearance of Albumin and Light Chains in HemoDialysis Patients: a safety device study. Blood Purification. 1990;15(4):468-478. doi:10.1016/S0272-6386(12)70364-5

72. Krishnasamy R, Hawley CM, Jardine MJ, et al. Design and methods of the REMOVAL-HD study: a tRial Evaluating Mid cut-Off Value membrane clearance of Albumin and Light chains in HaemoDialysis patients. BMC Nephrol. 2018;19(1):89. doi:10.1186/s12882-0180883-8
73. Cho N-J, Park S, Islam MI, et al. Long-term effect of medium cut-off dialyzer on middle uremic toxins and cell-free hemoglobin. PLoS One. 2019;14(7):e0220448. doi:10.1371/journal.pone.0220448

74. Kalantar-Zadeh K, Kilpatrick RD, Kuwae N, et al. Revisiting mortality predictability of serum albumin in the dialysis population: time dependency, longitudinal changes and population-attributable fraction. Nephrology Dialysis Transplant. 2020;20(9):1880-1888. doi:10.1093/ndt/gfaa128

75. Kaysen GA, Johansen KL, Cheng SC, et al. Trends and outcomes associated with serum albumin concentration among incident dialysis patients in the United States. $J$ Ren Nutr. 2008;18:323-331. doi:10.1053/j.jrn.2008.04.002

76. Medicare Program. End-Stage Renal Disease Prospective Payment System, Payment for Renal Dialysis Services Furnished to Individuals With Acute Kidney Injury, and End-Stage Renal Disease Quality Incentive Program. Fed Regist. 2020;85:421 32-42184.

77. Eknoyan G, Beck GJ, Cheung AK, et al. Effect of dialysis dose and membrane flux in maintenance hemodialysis. New Engl J Med. 2002;347(25):2010-2019. doi:10.1056/NEJMoa021583

78. Locatelli F, Martin-Malo A, Hannedouche T, et al. Effect of membrane permeability on survival of hemodialysis patients. J Am Soc Nephrol. 2003;42(3):645-654. doi:10.1016/j.ajkd.2003.07.016

79. Alves FC, Sun J, Qureshi AR, et al. The higher mortality associated with low serum albumin is dependent on systemic inflammation in end-stage kidney disease. PLoS One. 2018;13:e0190410. doi:10.13 71/journal.pone.0190410

80. Stenvinkel P, Barany P, Chung SH, et al. A comparative analysis of nutritional parameters as predictors of outcome in male and female ESRD patients. Nephrol Dial Transplant. 2002;17:1266-1274. doi:10.1093/ndt/17.7.1266

81. YeunJY, LevineRA, MantadilokV, et al.C-reactive protein predicts all-cause and cardiovascular mortality in hemodialysis patients. $\mathrm{Am}$ J Kidney Dis. 2000;35:469-476. doi:10.1016/s0272-6386(00)70200-9
The International Journal of Nephrology and Renovascular Disease is an international, peer-reviewed open-access journal focusing on the pathophysiology of the kidney and vascular supply. Epidemiology, screening, diagnosis, and treatment interventions are covered as well as basic science, biochemical and immunological studies. The manuscript management system is completely online and includes a very quick and fair peer-review system, which is all easy to use. Visit http://www.dovepress.com/testimonials.php to read real quotes from published authors. 